\title{
1. Social policy and development: an overview
}

\author{
James Midgley
}

As the social services of Western countries expanded in the years after the Second World War, some academics took the view that it would be worthwhile to study and assess the impact of government social policies. At about the same time, others were of the opinion the process of development, which was being given high priority by the governments of the newly independent developing nations at the time, was worthy of academic scrutiny. As a result, two new interdisciplinary fields known as social policy and development studies emerged at universities in Europe, North America and in other Western countries. While social policy was primarily concerned with the social services in these countries, development studies focused on the economic policies of governments in the Global South. Although both fields had a distinctly practical bent, they drew liberally on established social science disciplines to enhance their intellectual content.

In some cases, social policy and development studies emerged out of existing social work and colonial administration training programmes, but separate academic departments as well as centres and institutes devoted to both fields were also created. In addition, courses in both subjects were introduced within established disciplines, especially economics, sociology and political science. In time, both launched their own journals and established professional associations, and by the 1960s a significant number of books, journal articles and research reports had been published. In addition to offering professional undergraduate and graduate courses, doctoral education was introduced to prepare students to assume leadership positions in both fields. The work of academics in social policy and development studies began to influence governments as well as international organizations, foundations and nonprofits, and policy-relevant contract research for these organizations was also undertaken. Scholarly inquiry that was not of direct policy relevance was also pursued and often it was of a critical nature, challenging prevailing academic ideas and policy approaches. 
Although social policy and development studies are now well established, they remain distinct and there is little sharing of ideas and information between them. With few exceptions, social policy scholars have paid little attention to the work of their colleagues in development studies, and similarly those in development studies remain largely ignorant of the knowledge generated in social policy. They seldom read each other's literature and hardly ever attend each other's conferences. They infrequently collaborate on joint research projects. However, it is widely recognized that both fields overlap. Both are concerned with the promotion of social well-being even though they do so in different ways. Social policy pursues this agenda by studying the social services and the politics of social policy making, while development studies is primarily concerned with the way policies and programmes rooted in economic growth generate prosperity.

This chapter reiterates earlier calls for closer collaboration between social policy and development studies. It contrasts the two fields, discusses their evolution and current characteristics and shows they have not only enhanced knowledge but also contributed to policy formulation in each field. It then reviews the now extensive research undertaken into social welfare in the nations of the Global South, arguing that this research paves the way for closer collaboration between social policy and development studies. Focusing on how social policy functions in the context of economic development, it addresses issues of mutual concern that should be conducive to forging a partnership between scholars from social policy and development studies, as well as cognate disciplines. It may ultimately result in the synthesis of their work.

\section{SOCIAL POLICY AND WELFARE}

Although social policy was only recognized as an academic field in the 1950 s, it is rooted in centuries-old debates about how societies can promote the well-being of their citizens. Since ancient times, religious scholars have exhorted the faithful to care for those in need and behave in ways that foster the common good. Secular writers also offered prescriptions for how rulers should enhance social well-being. In some cases, very detailed instructions were given. For example, Kung Fu Tzu (or Confucius, as he is known in the West) provided a comprehensive set of practical guidelines for achieving this goal which continues to exert influence in East Asian societies today. Others offered visionary proposals for creating perfect societies. Beginning with Plato, utopian thinking shaped the Western reformist agenda, finding ultimate expression in the 
late nineteenth century with the adoption of legislative initiatives that sought to address social problems and raise living standards. Compulsory education, labour reforms, the introduction of social insurance, improvements in public health and the creation of statutory welfare services were only some of the steps taken by governments that embodied the utopian vision. As policies of this kind multiplied in subsequent years, the need for systematic scholarly enquiry into statutory social welfare was widely recognized.

Academic studies of social welfare first emerged in the early twentieth century as scholars traced the history of social services, evaluated their impact and offered normative accounts which legitimated their expansion. Many were associated with the emerging profession of social work, while others came from disciplines such as economics, history and sociology. Some urged the expansion of social insurance, while others addressed working conditions and the problem of unemployment. Many focused on poverty, calling on governments to remedy its causes and effects. The authors of these studies were often involved in campaigns for the expansion of statutory welfare and in some cases they assumed office and implemented social reforms. Arguably the best example is Clement Attlee, whose book on social work, which was published in 1920, outlined an activist agenda for social change which came to fruition when he became Prime Minister of the United Kingdom (UK) in 1945. Other Fabians such as the Webbs, who published extensively on welfare issues, also shaped this agenda as did Beveridge, whose work on unemployment meshed with Keynes's analysis to call on governments to intervene and promote economic and social prosperity. These efforts resulted in the massive expansion of state welfare in the UK and other Western countries such as the United States, France, Germany and the Scandinavian nations.

The emergence of the so-called 'welfare state' in these countries created new opportunities for the systematic study of social welfare. In addition, the need to train administrators who could implement and effectively manage government social policies was recognized. Relevant courses in what was known as social administration were established in the UK, while in the United States statutory welfare agencies often recruited their staff from schools of social work. An important development was the creation of the Department of Social Science and Administration at the London School of Economics, which built on its history of training social workers to formulate a coherent approach to the study of government social policy. Led by Richard Titmuss, who was appointed its first professorial head in 1950, the department prompted the creation of social policy as an academic field. Although the study of social policy 
was dominated by British scholars in its formative years, comparable analyses of government social policies emerged in other Western countries. However, these accounts were not always available in English, hampering the emergence of a comparative perspective in the field. The major exception was the United States, where research into social policy was widely disseminated in the UK and other English-speaking countries. In addition, scholars in disciplines such as sociology, political science and economics also began to study social policy, and in continental Europe where academic departments of social administration did not emerge, research in the field was largely pursued by scholars in these disciplines.

Social policy's formative commitment to training administrators was soon augmented by scholarly analyses of the evolution, features, normative dimensions and impact of state welfare. Of particular importance was the formulation of paradigmatic normative interpretations which offered value-based legitimations of government intervention. Titmuss's own work articulated the influential and beguiling idea that welfare should be regarded as a form of collective altruism which gives expression to the deeply held caring values found in all societies. He regularly juxtaposed his view of statutory welfare as an unconditional gift against individualist, market-based interpretations which he claimed were inimical to well-being (Titmuss 1971). A similar normative account was Marshall's (1950) conception of social welfare as a social right. Reflecting the international preoccupation with human rights at the time, Marshall claimed that citizens have an unconditional right to education, health care, social security and other social services. By guaranteeing the right to welfare, governments built on the centuries-old struggle for civil and political rights to create of a just society.

Both Marshall and Titmuss reflected the then popular view derived from social liberalism and social democracy that government should intervene to mitigate the excesses of the market and raise living standards. Variously known as institutionalism, welfare statism or simply as welfarism, this belief exerted an almost hegemonic influence in social policy circles in the post-war years and provided a normative framework for much enquiry in the field. However, it was eventually challenged by the ascendancy of market liberalism, popularly known as neoliberalism. Although vigorously rejected by mainstream social policy writers, market liberal prescriptions were implemented in the 1980s after radical right political parties were elected in the UK, the United States and elsewhere. In addition to liberalizing the economy, these governments sought to curtail the expansion of state welfare and promote greater individual responsibility for welfare. A new body of scholarship, emanating mostly 
from the United States, now offered a very different interpretation of the role of the state in social welfare. Government welfare was criticized by best-selling authors such as Gilder (1981) and Murray (1984) for being inefficient and wasteful, fostering dependency and causing high unemployment and economic stagnation. Scholars such as Mead (1986) argued that instead of passively claiming their rights, welfare recipients should fulfil their obligations to secure employment, conform to societal norms and discharge the duties of citizenship. As these and similar ideas exerted influence, major changes to the social services were introduced, not only in the United States but also in Europe and other parts of the world as well. Privatization, retrenchment, increased conditionalities, welfare-to-work and outsourcing now characterized social policy in many countries.

The value assumptions institutionalized in social policy in the 1960s were challenged by critics of other normative persuasions as well. Marxist writers such as O'Connor (1973), Gough (1979) and Offe (1984) claimed that social policy was being used by the owners of capital and their political allies to mollify discontent and control working people. Wilson (1977) and Pascall (1986) were among the first of many feminist scholars to point out that government welfare programmes were based on a male breadwinner model that reinforced institutionalized patriarchal values and discriminated against women. Writing from a multicultural perspective, Wiliams (1989) drew attention to the ethnocentricity and discriminatory features of state welfare, while radical populists challenged the idea that governments should be primarily responsible for social welfare, arguing that community initiatives should be given far higher priority. At the same time, religious traditionalists such as Olasky (1992) maintained that the family should be recognized as the primary welfare institution and that its role should be reinforced by government support for faith-based charities. These different normative interpretations challenged the dominance of social democratic welfarism, but it continues to exert a potent influence in the field, influencing the way most social policy scholars view the role of the state in social welfare today. These accounts also reveal the extent to which the study of social policy was no longer shaped by British writers associated with academic departments of social policy and administration, but increasingly by political scientists, sociologists, historians and scholars in other disciplines.

Although social policy has been primarily engaged in normative debates about state welfare, accounts of the dynamics of social welfare and typologies of welfare systems have also been popular. Myles and Quadagno (2002) reveal that a great deal of effort has been devoted over the years to identifying the factors responsible for the growth of 
government welfare in Western countries since the Second World War. Pioneered primarily by political scientists, numerous but competing interpretations of these dynamics were offered. These highlight the role of industrialization, interest group politics, working class pressures and the influence of civil servants and political elites in initiating and shaping welfare expansion. Although none of these accounts have been universally accepted, they reveal the extent to which social policy scholars have engaged in quite sophisticated theoretical speculation about the reasons for the expansion of state welfare, and how empirical data has been used to support their claims.

Typologies and stadial interpretations of the evolution of state welfare have also been popular. Dichotomies such as Wilensky and Lebeaux's (1965) formative residual versus institutional model have been augmented by a plethora of classifications of domestic arrangements and normative preferences. They have also been used for comparative purposes to classify the welfare systems of different countries. Arguably the most celebrated is Esping-Andersen's (1990) 'three worlds of welfare model', which has survived sustained critiques to be repetitively cited in the literature. In turn, typologies have been linked to stadial interpretations such as those by Jessop (1994) and van Keesberger and Hemerijck (2012) which conceptualize complex historical processes in terms of discrete phases in the evolution of government welfare. Typically, the growth of the Western welfare state is said to begin with Keynes and Beveridge, transitioning to a neoliberal stage, followed by a stage characterized by crisis, and more recently a pluralistic consolidation of state welfare marked by recalibration and innovations such as social investment.

As mentioned earlier, the research undertaken by social policy scholars over the years reveals the extent to the state is viewed as the prime agent of welfare. Although the statist preference has been widely challenged, scholarship in the field remains largely focused on government responsibility, and the role of nonprofits, local communities and commercial providers has been neglected even though it is recognized that these agents now feature much more prominently in the current pluralist social welfare mix. Few social policy scholars today are wedded to the idea that governments should be the exclusive providers of social services, but they continue to believe that the state should proactively direct, coordinate, fund and be ultimately responsible for the welfare of their citizens. As Midgley (2013) observes, the Eurocentric, social democratic origins of this normative position will be readily apparent, and although challenged by the realities of welfare in other parts of the world, it pervades the field and serves as a paradigmatic framework for social policy 
research in many countries. It will be shown later that this approach contrasts with the multidimensional and pluralist interpretations that have evolved in development studies.

\section{DEVELOPMENT STUDIES AND SOCIAL PROGRESS}

Like social policy, development studies is rooted in ideas that have ancient provenance. Arguably the most important of these is the belief in progress: the contention that societies evolve over time from simple to complex systems marked by economic prosperity and high levels of welfare. While progress was historically believed to be driven by forces beyond human agency, it was gradually recognized that humans themselves could direct the process of change and bring about significant improvements in social conditions. This view found expression in the late nineteenth century in the adoption of progressive economic and social policies. Reflecting the popularity of evolutionary thought at the time, social liberals advocated judicious state-sponsored reforms, while social democrats called for a more expansive role for government characterized by economic planning, regulation and extensive social services. Marxists went further, calling for the complete socialization of the economy and the redistribution of productive surpluses to the whole population. These different normative interpretations all gave expression to progressive ideas and a belief in the desirability of state intervention.

These notions also informed economic thinking in the early decades of the twentieth century. In Western countries Keynesian ideas displaced the dominance of laissez-faire neoclassicism, while in the Soviet Union centralized economic planning sought to promote industrialization through state ownership of the economy. In their different ways, both embodied the claim that social progress could be realized through economic development. This idea appealed to the nationalist leaders who were campaigning for independence from European imperial rule at the time. When the former colonial territories secured sovereignty after the Second World War, economic planning inspired by the Soviets combined with Keynesian growth proposals to inform the five-year industrial development plans published by the new central planning agencies established in many developing countries. However, not everyone agreed that the key to social progress lay in industrialization, and in some countries such as Tanzania and China, improving rural conditions was given high priority. This was also the case in India, where Nehru's commitment to industrialization contrasted with Gandhi's belief in rural development. This dual focus on modern industry and rural community 
development subsequently became two major intellectual thrusts in development thinking which, respectively, found expression in national planning and local community development.

These events helped to launch the academic study of development. Like social policy, development studies emerged in the Western countries after the Second World War, and in some countries such as the UK it was initially associated with university training courses for colonial administrators. Some of these courses subsequently evolved into major interdisciplinary centres. In addition, scholars working in established disciplines such as economics, political science, sociology and anthropology also became interested in development. Economists gave the lead and attention soon focused on how agrarian, post-colonial societies could be transformed into modern, industrial states. At the same time, courses in community development were established in both the metropolitan and developing countries. Although primarily concerned with training community workers, they also engaged in research, producing a large number of reports and monographs on the subject.

In the 1950s, most development economists believed that by expanding domestic industry governments would initiate a virtuous process of economic growth that would modernize traditional societies. 'Unproductive' labour would be drawn out of the subsistence agricultural sector into the small modern wage economy that had emerged in many colonial territories. By expanding wage employment, incomes would rise and demand for domestic goods and services would increase. In turn, this would stimulate more industrial investment, create more jobs, raise incomes and promote widespread prosperity. A voluminous literature authored primarily by economists with Keynesian proclivities such as Nurkse (1953), Lewis (1955) and Rostow (1960, 1963) rapidly evolved to provide detailed proposals for how this process could be initiated. These ideas were supported by sociologists, political scientists and psychologists such as Hagen (1962), Hozelitz (1960) and McClelland (1964) who fostered the emergence of a paradigmatic interpretation of development that became known as modernization theory. In addition to modernizing economic production, governments were urged to adopt policies that would transform the traditional culture and promote individualistic and secular attitudes compatible with the needs of an industrializing society.

However, modernization theory was soon challenged. As mentioned earlier, some such as Gandhi and Nyerere argued that living standards should be raised through agricultural improvements rather than industrialization. Although this belief prompted the introduction of numerous state-sponsored rural community development programmes in the Global South in the 1950s (see Chapter 23 of this book), they too 
were criticized largely because they were sponsored by governments, and said to be bureaucratic, corrupt, controlled by politicians and indifferent to the needs of rural people. In response, a much more activist style of community development emerged. This approach sought to mobilize communities to confront the bureaucracy as well as local elites who, it was claimed, had hijacked community development for their own purposes. Known as community action or community participation, it would give authentic expression to people's aspirations by helping them to determine their own needs and find solutions to their own problems. The community development literature, which had focused on promoting self-help among rural people, was now augmented by radical interpretations such as Freire's (1970) 'conscientization' approach.

The emergence of community activism was also inspired by revolutionary anticolonial movements which drew on Maoist ideas to launch major insurrections against several governments at the time. In the 1970s, these developments influenced another radical critique of modernization theory. Known as international structuralism or dependency theory, it was pioneered by neo-Marxist scholars in the Global South (and particularly in Latin America) such as Frank (1967) and Cardoso (1972) who challenged the view that endogenous industrialization would raise living standards in the developing world. They drew attention to the global patterns of exploitation that persisted after the formal end of the colonial era, arguing that the nations of the Global South were caught in a web of exploitation that favoured the Western countries, large international corporations and global capitalism. Faced with these realities, industrialization policies were doomed to failure and governments, they proposed, should resist international capitalism and delink from the global economy.

The work of the dependendistas was compatible with the growing realization in development studies that policies adopted at the national level needed to be accompanied by international reforms that addressed global inequities. In 1974, the United Nations launched the New International Economic Order (NIEO) initiative which advocated for equitable trade, increased international aid and greater power sharing among the world's nations. Subsequently, the Brandt Commission (1980) produced a detailed set of proposals for enhancing North-South cooperation in development. As Moyn (2018) suggests, these events stimulated the emergence of a growing academic literature on global social justice and international human rights.

Another critique of the modernization approach came from development economists such as Seers (1969) and Myrdal (1971) who argued that the pursuit of industrialization had produced a highly distorted process of development in which the impressive rates of economic 
growth achieved by many countries in the post-war years had not created wage employment on a sufficient scale to reduce the incidence of poverty. Instead of creating jobs and raising standards of living, they claimed that the benefits of growth had accrued disproportionately to political, administrative and military elites, the business community, professionals and the civil service, leaving the bulk of the population behind. The problem, they argued, should be addressed by the adoption of egalitarian social policies that would foster inclusive development and raise living standards for all.

International organizations such as the United Nations, International Labour Organization and World Bank were sympathetic to this approach. In a major speech to the Governors of the World Bank in 1973, President Robert McNamara announced that the Bank's lending policies would give high priority to reducing poverty. In an important study (Chenery et al. 1974) senior staff at the Bank collaborated with the Institute of Development Studies at the University of Sussex in the UK to examine income inequality in the developing world and to propose policies that would address the problem without affecting economic growth. Earlier, the ILO had launched fact finding missions to several developing countries to determine why industrialization had failed to significantly reduce poverty. These studies found that instead of absorbing the large numbers of rural workers who came to the cities in search of work, industrial policies had created a large and growing informal urban economy, situated in sprawling informal settlements marked by poverty and deprivation. It was soon recognized that modernization theory had not fulfilled its promise, and that an alternative approach that focused on poverty eradication was needed. To achieve this goal, governments were urged to abandon their commitment to modernization and to ensure that the basic social needs of their citizens were met.

The ILO and the United Nations became leading sponsors of this approach. Instead of waiting for economic growth to raise living standards, they advised governments to adopt policies that would address the educational, health, nutrition, housing and other needs of their citizens. Leading development scholars, notably Streeten and his colleagues (Streeten and Burki 1978; Streeten et al. 1981; Stewart 1985) provided an intellectual basis for this approach and offered an alternative to Myrdal and Seers's egalitarianism by emphasizing what Moyn (2018) describes as a minimal sufficiency standard for social welfare. This approach has now been widely adopted in development studies. Instead of seeking to address inequality, many scholars believe that it is more feasible to ensure that people's basic needs are met. This idea influenced the 
adoption of the Millennium Development Goals and the Sustainable Development Goals by the member states of the United Nations.

These developments were accompanied by a critique of modernization theory that focused on the environment, claiming that the relentless pursuit of economic growth through industrialization had caused considerable ecological damage and fostered wasteful consumerism. Unless checked, it would ultimately have disastrous consequences (Meadows et al. 1972). This analysis attracted widespread attention, resulting in the appointment of a major international commission by the United Nations in 1983. Known as the Brundtland Commission, it did not reject the need for economic growth, but argued that development should be sustainable, meeting current needs without compromising the needs of future generations (Brundtland Commission 1987). Since then, these ideas have been widely accepted in development studies.

Equally trenchant critiques challenged the way industrialization had fostered male wage employment and perpetuated conventional gender roles. One of the first came from Boserup (1970), who pointed out that while women made a major contribution to economic development by working in agriculture, trade, crafts and other productive activities, their role was ignored. A powerful international movement now emerged that campaigned not only for women's economic contribution to be properly recognized but also for an end to gender discrimination and oppression. These arguments resulted in far more attention being paid to gender in development studies, especially after the United Nations launched the first United Nations Decade for Women in 1975. Since then, feminist scholarship into development has increased exponentially, and supported by international conferences and activist women's groups, an egalitarian gender approach has featured prominently in the field.

However, as in social policy, these progressive ideas were challenged in the 1980s by the rise of market liberalism. This approach was fostered by the electoral success of radical right political parties in several Western countries at the time, and heavily influenced by leading neoliberal scholars in Western countries such as von Hayek $(1944,1948)$ and Friedman (1962). Of particular importance was the appointment of market liberals to key executive positions at the International Monetary Fund (IMF) and the World Bank, and under their leadership both organizations now required governments receiving aid to liberalize their economies, privatize state enterprises and reduce social spending. These radical policy changes would, it was argued, challenge the statism that had dominated development since the end of the Second World War, and foster rapid economic growth and prosperity. Since many governments had become heavily indebted, they had little choice but to comply with 
these structural adjustment conditionalities as they were known. With the notable exception of development economists such as Bauer (1971), Lal (1983) and de Soto (1989), neoliberalism enjoyed little support in development studies, but it was widely adopted in policy circles. In addition to reducing the role of governments, it paved the way for the rapid increase of nonprofit organizations and commercial providers in the field which were believed to offer superior services to statutory agencies. They now became the primary recipients of international aid and began to play a key role in development, especially in low-income countries.

Despite rejecting neoliberalism, many development scholars were influenced by the individualism of the market liberal interpretation. The formative focus on national and community-level interventions in development studies was augmented in the 1990s by a new emphasis on households, which were viewed as the primary agents of development. Since they act rationally to promote their interests and livelihoods, their capabilities should be enhanced through various development initiatives. In addition to agricultural inputs, Polak (2008) proposed that they be provided with credit and technical assistance and helped to establish micro-enterprises. Their human capital and resourcefulness should be improved through training and educational programmes, and policies that assist them to accumulate assets should be introduced. Unlike neoliberalism, the livelihoods approach, as it became known, gained significant support in development studies, particularly as Sen's (1999) writings informed this approach. Assisting the United Nations Development Programme (UNDP) to formulate these ideas (UNDP 1990) he famously redefined development as a process of enhancing people's choices.

The emergence of numerous interpretations of the development process and the formulation of a variety of normative and policy prescriptions reveals the complex, multidimensional nature of development studies. Unlike social policy, which is primarily concerned with the provision of services by national governments, development studies analyses interventions that operate at multiple levels including households, communities and nations and, as mentioned earlier, it also addresses international economic and social policies. It is also more pluralistic than social policy which, as suggested earlier, has been largely concerned with statutory interventions, paying relatively little attention to the role of nonprofits which feature much more prominently in development studies. Although social policy scholars have analysed the ways families and particularly women engage with statutory welfare, there is more emphasis on households and their efforts to enhance their livelihoods in development studies. Both fields have been inspired by social democratic politics and Keynesian economics, and have resisted the market liberal tide, but it has 
been shown already that conceptual and normative innovations that diverge substantively from statism have been more common in development studies. The livelihoods approach, the long-standing commitment to community development and the promotion of sustainable development reveal the extent to which development studies has adopted multiple, competing normative interpretations. To complicate matters further, some development studies writers have even challenged the very existence of the field itself. These members of the anti or post-development school such as Escobar (1995) and Sachs (2010) take a very negative view of development studies, its assumptions and policy prescriptions.

\section{THE STUDY OF SOCIAL WELFARE IN THE DEVELOPMENT CONTEXT}

As suggested at the beginning of this chapter, studies of social welfare in the Global South undertaken by scholars in both social policy and development studies (as well as other disciplines) creates a terrain on which closer collaboration between social policy and development studies can be forged. This research focuses on statutory welfare services but it also addresses issues of economic and social development and, for this reason, offers a useful way of bridging the respective interests of these two fields. The knowledge of statutory welfare pioneered by social policy will benefit from the study of development, while the focus on development can be informed by an understanding of how welfare institutions operate in the Global South.

Contrary to the generally accepted view that the literature on social welfare in the developing world is limited and of 'recent vintage' (Haggard and Kaufman 2008, p. 1), a great deal has been published on the subject over many years. In fact, the first accounts of this kind emerged during the colonial era when, as Hodge (1973) revealed, the authorities undertook official inquiries into social problems or the nascent social services. In some cases, these inquiries paved the way for major social reforms. For example, Harrison (2011) notes that the Moyne Commission into political unrest in the British Caribbean territories in the 1930s fostered the introduction of social services during the Second World War. At this time Mair, an anthropologist, published the first major study of social welfare in the British colonies (Mair 1944). She noted that the British government had authorized the expansion of education, health care and other social services by allocating funds through the Colonial Development and Welfare Acts, the first of which was passed in 1929. She also observed that the League of Nations, which had been founded in 
1919, had urged the European imperial powers to promote statutory social welfare in their possessions.

The United Nations, together with its affiliate organizations such as the International Labour Organization (ILO), the United Nations Children Fund (UNICEF) and World Health Organization (WHO), made important contributions to the study of social welfare in the newly independent developing countries. These organizations vigourously advocated for the expansion of government welfare by adoption resolutions, convening conferences and producing a plethora of reports which shaped thinking about social policy in the Global South. The United Nations was also instrumental in promoting the integration social and economic planning at the national level. It encouraged the training of social planners who could work closely with economists to formulate national development plans which prioritized the integration of economic and social goals and the expansion of social services. Academics were often invited to advise on these developments and some, such as Myrdal, played a key role in promoting the growth of welfare programmes in the developing countries. They also advised the governments of the newly independent countries on social policy. One of the first was Titmuss and his colleague Abel-Smith (1961), who helped the government of Mauritius to design its welfare system.

As Midgley (2014a) discusses, the United Nations made a major contribution by pioneering social development as distinctive approach to social welfare in the Global South. This approach sought to end the compartmentalization of social and economic policies by ensuring that economic development plans had a demonstrable social welfare impact, while social programmes contributed positively to development. The governments of many developing countries concurred with the principle that economic development and social welfare goals should be given equal priority, and it was adopted by national planning agencies, social sectoral ministries and community development programmes. In particular, local economic projects that contributed directly to improvements in living standards were given high priority. However, despite its importance, social development was almost entirely ignored by Western social policy writers and attracted little attention in development studies. This can be partly attributed to a dearth of scholarly literature on the subject. Although some books and a journal devoted to social development appeared (Jones and Pandey 1981; Sanders 1982), it remained focused on practical interventions which had limited appeal in scholarly circles.

On the other hand, the basic needs approach mentioned earlier generated a substantive literature and provided a normative framework conducive to the expansion of social policy in the Global South. 
Although essentially concerned with welfare, basic needs was inspired by scholars in development studies (supported by the ILO, the United Nations and other international organizations) rather than social policy writers. However, the basic needs approach was fiercely rejected by market liberals and was largely supplanted by the adoption of structural adjustment and other neoliberal policies in the 1980s. Nevertheless, as noted previously, it paved the way for the Copenhagen World Summit of Social Development in 1995 and the adoption of the Millennium Development Goals and subsequently the Sustainable Development Goals (see Chapter 6 of this book). Closely aligned with social development thinking, both gave expression to the idea that governments have an obligation to provide basic welfare services to their citizens as of right.

Despite the influence of neoliberalism, the academic literature on social welfare in the Global South by both social policy and development studies scholars grew steadily. Much of it was descriptive, focusing on the social services and their implementation. As far as can be ascertained, the first book on the subject was by Livingstone (1969), a development studies scholar at the University of Manchester. In addition to tracing the history of the social services, he drew attention to various issues relating to their role and function. One of these was the failure to demonstrate how the social services contributed to economic development. This was to be a focus of subsequent debates in the field. Other formative studies, such as a comprehensive textbook on social policy in developing countries by Hardiman and Midgley (1982), also addressed key policy issues. They challenged the then prevalent view that the social services in these countries were limited and underdeveloped. In fact, they explained that most governments had incrementally expanded the social services and that access to education, health care, family welfare and other services had increased significantly since colonial times. On the other hand, they drew attention to the inappropriateness of welfare policies which were largely based on those of the Western countries. The emulation of Western approaches, they argued, resulted in services that were concentrated in urban areas, wasteful and neglectful of the needs of the rural majority. A similar account summarizing the key issues affecting the social services was published by Jones in 1990. In addition to these accounts of social policy in the developing world as a whole, numerous books dealing with social welfare policy in particular countries such as China (Dixon 1981), Nigeria (Onokerhoraye 1984) and India (Dubey 1973) were published at this time.

These mostly descriptive studies were augmented by theoretical and critical accounts of the way social policies functioned in the Global South. MacPherson (1982) offered one of the first analyses of this kind. 
Drawing on dependency theory, he linked the notion of policy inappropriateness to the exploitative nature of development and the failure of social welfare policies to promote the well-being of the people of the developing world. Midgley (1984) offered a similar critique by showing how social security, which had been based on Western approaches, had not only failed to reduce but had in fact exacerbated inequality. In 1987, MacPherson and Midgley co-authored a book intended to inform Western social policy scholars about social welfare in the developing world, and to show how a greater knowledge of social policy in the Global South could inform their own research.

The question of the relationship of social welfare to development came into sharp focus as several studies of the social policies of the rapidly industrializing countries of East Asia were published during the 1990s. The orthodox view that social welfare and economic development were antithetical seems to be at odds with the observation that countries such as Taiwan, Hong Kong, Singapore and South Korea were recording high rates of economic growth even though their social services were also expanding. Offering insights into this question, scholars such as Holliday (2000), Kwon (2005) and Midgley and Tang (2001) drew on the developmental state concept originally formulated by Johnson (1982) to suggest that the drive for industrialization was aided by the social services and particularly education, health care and social security. The East Asian 'tigers', they argued, had formulated a productivist social policy model which was not only compatible with but also supportive of economic growth. This contention addressed the issue Livingstone had raised in 1969 about the relationship between social welfare and economic development. The notion of developmental welfare also comported with the social development approach which sought to link social and economic policies within a holistic development process (Midgley 2014a).

The idea that social policy should contribute to economic development has recently found expression in the notion of social investment. Popularized by European social policy writers (Bonoli 2013; Hemerijck 2017; Morel et al. 2012), it responds to the criticism that the 'welfare state' has failed to adapt to changing social and economic realities, and contributed to the economic stagnation and high levels of unemployment that characterized the European nations in the 1990s. Instead of transferring resources to 'passive' welfare recipients, governments are urged to adopt 'active' social policies that invest in people's capabilities and foster their integration into the productive economy. Education, skills training, family leave policies, child care and other services that support employment as well as wider economic development goals should be given higher 
priority than conventional income maintenance and family welfare services. These ideas share many similarities with social development and developmental welfare, but their contribution has not been acknowledged by Western social policy writers who, Midgley (2013) suggests, would benefit from the insights of these approaches.

A helpful development is the recent interest among social policy scholars in what is called 'global social policy' (Deacon 2007; Yeates 2008). This field focuses attention on the work of the international agencies, donors and nonprofits, and transcends social policy's conventional focus on the nation state. It has also exposed social policy scholars to the important role these agents play in promoting social development and social welfare in the Global South. It is not constrained by the conventional parameters of social policy, and although pioneered by social policy writers it helps to bridge the gap between social policy and development studies.

The recent surge of interest in income transfers in development studies also has the potential to forge closer cooperation between the two fields. Although development studies scholars had paid little attention to the rapid expansion of social security in the Global South in the years following the Second World War, it attracted growing attention in the 1990s when several governments, mostly in Latin America, modified conventional social assistance schemes by paying income benefits to poor families, provided they complied with school attendance and other requirements (see Chapter 20 of this book). Cash transfer programmes were also given increasing priority in disaster relief and gradually it was recognized that they could, as Hanlon et al. (2010) suggest, make a significant contribution to poverty reduction by 'just giving money to the poor'. Other forms of social security such as universal child allowances and pensions are also being scrutinized for their impact on poverty. 'Social protection' was adopted in preference to the older term 'social security', and it has since become a major focus of scholarship in development studies.

However, the study of social protection in development studies has proceeded with little reference to the work undertaken into social security by social policy scholars. This is unfortunate since, as Midgley (2014b) points out, development studies has much to gain from being better acquainted with the study of social security in social policy. Major issues such as financing and affordability, managerial effectiveness and political opposition to statutory programmes have been analysed and debated by these scholars for many years and can inform development studies where these issues have not yet become prominent. At the same time, the author contends that Western social policy scholars have much to learn from their 
colleagues in development studies who have undertaken extensive research into social protection in the Global South. In addition, social policy scholars have paid little attention to non-formal and community-based social protection which functions in many migrant communities in the West. Clearly, far more collaboration between the two fields is needed.

It will be clear that, despite considerable overlap, much more should be done to promote collaboration between scholars in social policy and development studies who undertake research into social welfare in the Global South. Given a commitment on both sides, fairly simple steps can be taken to foster cooperation. They should make a concerted effort to become acquainted with each other's literature, attend each other's conferences and convene meetings where issues of mutual interest can be debated. Joint research projects culminating in joint publications should also be undertaken. These straightforward, practical steps could promote a deeper understanding of the approaches adopted in each field and lead to the production of useful knowledge with positive policy implications.

It is also clear that collaboration will provide opportunities to examine a complex range of issues that have direct relevance for the study of social welfare in the Global South. These include questions concerning the role of development in promoting social well-being and the respective importance that should be attached to economic and social processes. The respective role of the state, community, household and market in promoting social well-being also needs to be addressed in more depth. Political ideologies and the influence of competing agendas on government policies, as well as the interventions sponsored by nongovernmental organizations, foundations and international bodies, need to be analysed in more depth. Another issue of particular relevance to the study of social policy in the Global South is the need for an emic approach that focuses on existing, indigenous welfare institutions rather than imposing Western concepts and typologies, to analyse these institutions. Walker and Wong (2013) forcefully contend that this ethnocentric approach has impeded the study of social policy in the developing world, and Midgley $(2013,2017)$ agrees, arguing it has not produced plausible or useful accounts. By focusing on actual policy activities, appropriate knowledge of policy significance can be generated. For example, social policy analysis would benefit from focusing on the Sustainable Development Goals which, as suggested in Chapter 6 of this book, provide a major opportunity for social policy and development studies scholars to find common ground when studying social policy in the Global South.

There are many other issues that still need to be examined and debated jointly by social policy and development studies scholars which could 
promote a collaborative partnership concerned with the study of welfare institutions in the Global South. Chapter 2 of this Handbook by Surender sketches out an agenda for future debate which points the way forward and offers useful insights into how a partnership between social policy and development studies may be forged.

\section{REFERENCES}

Attlee, C.R. (1920). The Social Worker. London: Bell \& Sons.

Bauer, P.T. (1971). Dissent on Development. London: Weidenfeld \& Nicolson.

Bonoli, G. (2013). The Origins of Active Social Policy: Labour Market and Childcare Policies in Comparative Perspective. New York: Oxford University Press.

Boserup, E. (1970). Women's Role in Economic Development. London: Allen \& Unwin.

Brandt Commission (1980). North-South: A Programme for Survival. London: Pan Books. Brundtland Commission (1987). Our Common Future: From One Earth to One World. Oxford: Oxford University Press.

Cardoso, F.H. (1972). Dependency and Development in Latin America. New Left Review, 74, 83-89.

Chenery, H., Ahluwalia M., Bell, C., Duloy, J.H. and Jolly, R. (1974). Redistribution with Growth. Oxford: Oxford University Press.

Deacon, B. (2007). Global Social Policy and Governance. London: SAGE Publications.

de Soto, H. (1989). The Other Path: The Invisible Revolution in the Third World. New York: Harper \& Row.

Dixon, J. (1981). The Chinese Welfare System, 1949-1979. New York: Praegar.

Dubey, S.N. (1973). Administration of Social Welfare Programs in India. Bombay: Somaiya Publications.

Escobar, A. (1995). Imagining a Post-Development Era. In J. Crush (ed.), Power of Development. New York: Routledge, pp. 211-227.

Esping-Andersen, G. (1990). The Three Worlds of Welfare Capitalism. Cambridge: Polity Press.

Frank, A.G. (1967). Capitalism and Underdevelopment in Latin America. New York: Monthly Review Press.

Freire, P. (1970). Pedagogy of the Oppressed. New York: Herder \& Herder.

Friedman, M. (1962). Capitalism and Freedom. Chicago, IL: University of Chicago Press. Gilder, G. (1981). Wealth and Poverty. New York: Basic Books.

Gough, I. (1979). The Political Economy of the Welfare State. London: Macmillan.

Hagan, E. (1962). On the Theory of Social Change. Homewood, IL: Dorsey Press.

Haggard, S. and Kaufman, R.R. (2008). Development, Democrary and Welfare States: Latin America, East Asia and Eastern Europe. Princeton, NJ: Princeton University Press.

Hanlon, J., Barrientos, A. and Hulme, D. (2010). Just Give Money to the Poor: The Development Revolution from the Global South. Sterling, VA: Kumarian Press.

Hardiman, M. and Midgley, J. (1982). The Social Dimensions of Development: Social Policy and Planning in the Third World. New York: John Wiley \& Sons.

Harrison, J. (2011). The Colonial Legacy and Social Policy in the British Caribbean. In J. Midgley and D. Piachaud (eds), Colonialism and Welfare: Social Policy and the British Imperial Legacy. Cheltenham, UK and Northampton, MA, USA: Edward Elgar Publishing, pp. 55-70.

Hayek, F. von (1944). The Road to Serfdom. London: Routledge \& Kegan Paul. 
Hayek, F. von (1948). Individualism and Economic Order. London: Routledge \& Kegan Paul.

Hemerijck, A. (ed.) (2017). The Uses of Social Investment. New York: Oxford University Press.

Hodge, P. (1973). Social Policy: An Historical Perspective as Seen in Colonial Policy. Journal of Oriental Studies, 9 (3), 207-219.

Holliday, I. (2000). Productivist Welfare Capitalism: Social Policy in East Asia. Political Studies, 48 (4), 706-723.

Hozelitz, B.F. (1960). Sociological Factors in Economic Development. New York: Free Press.

Jessop. B. (1994). The Transition to Post-Fordism and the Schumpeterian Workfare State. In R. Burrows and B. Loader (eds), Towards a Post-Fordist Welfare State. New York: Routledge, pp. 13-37.

Johnson, C.A. (1982). MTTI and the Japanese Miracle: The Growth of Industrial Policy 1925-1975. Stanford, CA: Stanford University Press.

Jones, H. (1990). Social Welfare in Third World Development. London: Macmillan.

Jones, J. and Pandey, R. (eds) (1981). Social Development: Conceptual, Methodological and Policy Issues. New York: St Martin's Press.

Kwon, H. (2005). An Overview of the Study: The Developmental Welfare State and Policy Reforms in East Asia. In H.-J. Kown (ed.), Transforming the Developmental Welfare State in East Asia. New York: Palgrave Macmillan, pp. 1-26.

Lal, D. (1983). The Poverty of Development Economics. London: Institute of Economic Affairs.

Lewis, W.A. (1955). The Theory of Economic Growth. London: Allen \& Unwin.

Livingstone, A. (1969). Social Policy in Developing Countries. London: Routledge \& Kegan Paul.

MacPherson, S. (1982). Social Policy in the Third World: The Dilemmas of Underdevelopment. Brighton: Harvester.

MacPherson, S. and Midgley, J. (1987). Comparative Social Policy and the Third World. Brighton: Wheatsheaf.

Mair, L. (1944). Welfare in the British Colonies. London: Royal Institute for International Affairs.

Marshall, T.H. (1950). Citizenship and Other Essays. Cambridge: Cambridge University Press.

McClelland, D. (1964). A Psychological Approach to Economic Development. Economic Development and Cultural Change, 12 (2), 320-324.

Mead, L.M. (1986). Beyond Entitlement: The Social Obligations of Citizenship. New York: Free Press.

Meadows, D.H., Meadows, D.L., Randers, J. and Behrens, W.W. (1972). The Limits to Growth. New York: Universe Books.

Midgley, J. (1984). Social Security, Inequality and the Third World. New York: Wiley.

Midgley, J. (2013). Social Development and Social Welfare: Implications for Comparative Social Policy. In P. Kennett (ed.), A Handbook of Comparative Social Policy. Cheltenham, UK and Northampton, MA, USA: Edward Elgar Publishing, pp. 182-204.

Midgley, J. (2014a). Social Development: Theory and Practice. London: SAGE.

Midgley, J. (2014b). Social Development and Social Protection: New Opportunities and Challenges. In L. Patel, J. Midgley and M. Ulriksen (eds), Social Protection in Southern Africa: New Opportunities for Social Development. New York: Routledge, pp. 2-12.

Midgley, J. (2017). Social Welfare for a Global Era: International Perspectives on Policy and Practice. Los Angeles, CA: SAGE Publications.

Midgley, J. and Tang, K.L. (2001). Social Policy, Economic Growth and Developmental Welfare. International Journal of Social Welfare, 10 (4), 242-250. 


\section{Handbook of social policy and development}

Morel, N., Palier, B. and Palme, J. (eds) (2012). Towards a Social Investment Welfare State? Ideas, Policies and Challenges. Bristol: Policy Press.

Moyn, S. (2018). Not Enough; Human Rights in an Unequal World. Cambridge, MA: Belknap Press.

Murray, C. (1984). Losing Ground: American Social Policy, 1950-1980. New York: Basic Books.

Myles, J. and Quadagno, J. (2002). Political Theories of the Welfare State. Social Service Review, 76 (1), 34-57.

Myrdal, G. (1971). The Challenge of World Poverty: A World Anti-poverty Outline. Harmondsworth: Penguin Books.

Nurkse, R. (1953). Problems of Capital Formation in Underdeveloped Countries. London: Oxford University Press.

O'Connor, J. (1973). The Fiscal Crisis of the State. New York: St Martin's Press.

Offe, C. (1984). Contradictions of the Welfare State. Cambridge, MA: MIT Press.

Olasky, M. (1992). The Tragedy of American Compassion. Washington, DC: Regnery.

Onokerhoraye, A.G. (1984). Social Services in Nigera. London: Routledge \& Kegan Paul.

Pascall, G. (1986). Social Policy: A Feminist Analysis. London: Tavistock.

Polak, P. (2008). Out of Poverty: What Works when Traditional Approaches Fail. San Francisco, CA: Berret-Koehler.

Rostow, W.W. (1960). The Stages of Economic Growth: A Non-Communist Manifesto. Cambridge: Cambridge University Press.

Rostow, W.W. (1963). The Economics of Take-Off into Sustained Growth. London: Macmillan.

Sachs, W. (2010). Introduction. In W. Sachs (ed.), The Development Dictionary: A Guide to Knowledge and Power, 2nd edition. London: Zed Books, pp. xv-xx.

Sanders, D.S. (ed.) (1982). The Development Perspective in Social Work. Manoa, HI: University of Hawaii Press.

Seers, D. (1969). The Meaning of Development. International Development Review, $11(4), 1-6$.

Sen, A. (1999). Development as Freedom. New York: Knopf.

Streeten, P. and Burki, S.J. (1978). Basic Needs: Some Issues. World Development, 6 (3), $411-421$.

Streeten, P., Burki, S.J., Ul Haq, M., Hicks, N. and Stewart, F. (1981). First Things First: Meeting Basic Needs in Developing Countries. New York: Oxford University Press.

Stewart, F. (1985). Basic Needs in Developing Countries. Baltimore, MD: Johns Hopkins University Press.

Titmuss, R.M. (1971). The Gift Relationship: From Human Blood to Social Policy. New York: Vintage.

Titmuss, R.M. and Abel-Smith, B. (1961). Social Policies and Population Growth in Mauritius. London: Methuen.

United Nations Development Programme (UNDP) (1990). Human Development Report 1990. New York.

van Keesberger, K. and Hemerijck, A. (2012). Two Decades of Change in Europe: The Emergence of the Social Investment State. Journal of Social Policy, 41 (3), 475-492.

Walker, A. and Wong, C.K. (2013). The Ethnocentric Construction of the Welfare State. In P. Kennett (ed.), Handbook of Comparative Social Policy. Cheltenham, UK and Northampton, MA, USA: Edward Elgar Publishing, pp. 98-114.

Wilensky, H.L. and Lebeaux, C.N. (1965). Industrial Society and Social Welfare. New York: Free Press.

Williams, F. (1989). Social Policy: A Critical Introduction. Cambridge: Polity Press.

Wilson, E. (1977). Women and the Welfare State. London: Tavistock.

Yeates, N. (ed.) (2008). Understanding Global Social Policy. Bristol: Policy Press. 